Research CommentaRies: Food Systems Research Priorities oVer the NeXt 5 Years

\title{
Food webs and food sovereignty: Research agenda for sustainability
}

\author{
Charles Francis, ${ }^{\mathrm{a} *}$ Michelle Miller, ${ }^{\mathrm{b}}$ Molly Anderson, ${ }^{\mathrm{c}}$ Nancy Creamer, ${ }^{\mathrm{d}}$ Michelle Wander, ${ }^{\mathrm{e}}$ \\ Jacob Park, ${ }^{\mathrm{f}}$ Thomas Green, ${ }^{\mathrm{g}}$ and Brent McCown ${ }^{\mathrm{h}}$
}

Submitted June 5, 2013 / Revised July 29, 2013 / Published online August 20, 2013

Citation: Francis, C., Miller, M., Anderson, M., Creamer, N., Wander, M., Park, J., Green, T., \& McCown, B. (2013). Food webs and food sovereignty: Research agenda for sustainability. Journal of Agriculture, Food Systems, and Community Development, 3(4), 95-101. http://dx.doi.org/10.5304/jafscd.2013.034.010

Copyright (C) 2013 by New Leaf Associates, Inc.

\begin{abstract}
Future food production will be constrained by the scarcity of fossil fuel and fresh water as well as increasing intensity and unpredictability of weather

a* Corresponding author: Charles Francis, Professor, Department of Agronomy \& Horticulture, University of NebraskaLincoln; Lincoln, Nebraska 68583-0915 USA; +1-402-472-

1581; cfrancis2@unl.edu; and

Visiting Professor of Agroecology, Institute of Plant and Environmental Sciences (IPM), P.O. Box 5003, Norwegian University of Life Sciences (UMB), N-1432; Aas, Norway; +47 6496 6137; charf@umb.no

b Michelle Miller, Associate Director, Center for Integrated Agricultural Systems, University of Wisconsin, 1535

Observatory Drive, Madison, Wisconsin 53706 USA

c Molly Anderson, Chair in Food \& Sustainable Agricultural Systems, College of the Atlantic, 105 Eden Street, Bar Harbor, Maine 04609 USA

d Nancy Creamer, Professor, Director of Center for Environmental Farming Systems, Campus Box 7609, North Carolina State University, Raleigh, North Carolina 27695 USA

events and climate changes. The assurance of food security and equity for many consumers is complicated by concentration of ownership of land and other production resources, as well as a global corporate food systems model that is driven by profit at the expense of people and the environment. To assess potential alternatives to the contemporary global food chain, well focused research is needed on local food production and

e Michelle Wander, Professor/Director of the Agroecology and Sustainable Agriculture Program, University of Illinois at Urbana-Champaign, N-225 Turner Hall, MC-047, 1102 South Goodwin Avenue, Urbana, Illinois 61801 USA

f Jacob Park, Green Mountain College, One Brennan Circle, Poultney, Vermont 05764 USA

g Thomas A. Green, President, IPM Institute of North America, Inc., 4510 Regent Street, Madison, Wisconsin 53705 USA

h Brent H. McCown, Professor Emeritus, Department of Horticulture, University of Wisconsin-Madison, Madison, Wisconsin 53706 USA
\end{abstract}


food webs where small- and midscale family farms provide economic viability for rural communities and their regions. We suggest multiple and integrative research priorities in production, enterprise, and farm economics, environmental impacts of farming at different scales, and social and community consequences of value adding and economic multipliers in local food webs and systems as well as the structure of agriculture. Research into key questions on food security and how it relates to increased food sovereignty is clearly needed to assess creative food system alternatives for the future.

\section{Keywords}

food economics, food environmental impacts, food production, food systems, food systems research, rural communities

\section{Introduction and Rationale}

Growing debate in the research and development communities is bringing focus to local and regional food web options and their potential to promote food sovereignty. The current globalized food system - highly dependent on fossil fuels, fresh water, stable climate, and uninterrupted supply lines - is not likely the only model for long-term food security for all or even a majority of people. Concentration in land ownership, sources of production inputs including improved seed dominated by a few corporations, and tightly controlled processing and marketing infrastructure all contribute to the potential fragility of a single, industrial-model food system, which is especially dangerous for consumers with limited economic and natural resources. Corporations with power and control in the food system find little incentive to reach people in food deserts in poor areas, to assure equity of access to food at a reasonable price, and to promote long-term food security for economically disadvantaged groups. There is limited research directed toward potential of locally based food chains or webs that depend on local capital and labor and production resources internal to the farm, and that are designed to serve people and effectively employ capital to that end.

Although the Green Revolution was highly successful in raising production, improving economic conditions for farmers with fertile land and access to needed inputs, and reducing costs of key commodities, the negative environmental and social impacts of this singular strategy are now becoming apparent. How do we critically evaluate the broader consequences of the first Green Revolution, and thus anticipate and avoid results that may only concentrate and exacerbate hunger and other environmental and social costs? There is accord on the need for food security, but ongoing questions about the costs and benefits of achieving a degree of food sovereignty.

What types of research are needed to better understand the unintended consequences of wellmeaning food system strategies, and evaluate creative alternatives, adaptations, and integration of multiple opportunities? There are unanswered questions about life-cycle costs of long food chains and contrasting with those of local food webs. While considering obvious efficiencies of scale, there are researchable issues regarding the potential of small- and midscale family farms to adequately feed local people; to generate jobs through the development of on-farm and off-farm new business enterprises; to add value on the farm and in the rural community; to diversify labor options and land ownership in rural communities and small towns; and to inform individuals and communities about the process of establishing regional food networks. The economic multiplier effects of local processing and food sale through farmers' markets, community supported agriculture, and locally owned grocery stores have yet to be quantified in a rigorous way. Research on the health and economic impacts of food-related illnesses such as diabetes and obesity could reveal how fresh and local fruits and vegetables may replace less expensive, highly processed and calorie-dense foods. These questions are critical to evaluation of local food systems. Can tastier or more nutritious plant varieties be profitable if we reduce the need for "shipability" and "uniformity"? Can youth increase their consumption of quality food through their engagement in school or community gardens, helping reverse rising obesity rates among children (Creamer \&Dunning, 2012)?

Research is also needed to better understand local food systems that recycle nutrients, water, and 
energy to reduce costs. The cycling of human waste could be integral to future resource-efficient systems when studies provide viable technologies. Essential to creating a research agenda that objectively evaluates alternatives is an educational model that promotes creating thinking in the combining of theory and practice; in the integration of production, economic, environmental, and social concerns; and in better understanding of food webs and farming as human activity systems. Focus in the future on a research agenda that evaluates local food systems using methods from both biological and social sciences can help us better understand food security and sovereignty. A number of key issues were presented in the "Sustainable Agricultural Systems Science White Paper" from the U.S. Department of Agriculture (USDA) Research, Education, and Economics Division in 2012, and these are included in the following discussion of future food system research priorities (Office of the Chief Scientist, USDA, 2012). An articulate presentation of the rationale for diversified farming systems based on agroecological models as compared to industrial agriculture was provided by Kremen, Iles, and Bacon (2012).

\section{Specific Weaknesses in Current Food Systems}

We recognize serious challenges that must be faced during the current century in producing enough food for a growing human population, with many people concerned about improving their diets, while at the same time maintaining an environment favorable to us and other species. Dependence on a finite and potentially exhaustible fossil fuel reserve requires a new metric for evaluating energy efficiency (Zencey, 2013), overexploitation of fresh water requires seeking more efficient irrigation technologies (Postel, 2013), and complacency bred by two centuries of relatively benign climate must be redirected into the creative design of more resilient and durable food systems (Renner, 2013). Coupled with the drastic concentration of wealth and land resources in the hands of a few corporations and individuals, these global realities give reason to pause and assess how we might better prioritize research in farming and food systems.
We need to mobilize people and scarce resources to meet future food needs with attention and compassion to the importance of food security and supply, of equity in access to food, and a degree of food sovereignty. It is time to take seriously the statement that was agreed upon at the founding of the United Nations and supported by the Brundtland Report (WCED, 1987) that food is a buman right.

As we are currently imbedded in a monetary and policy environment that promotes globalization of economic activity and food trade, we devote limited research to alternatives such as local food systems and how we can "reconnect food, nature, and community" (Wittman, Desmarais, \& Wiebe, 2010) in ways that promote a degree of local control and food sovereignty. Food sovereignty was a term "coined to recognize the political and economic power dimension inherent in the food and agriculture debate and to take a proactive stance by naming it. Food sovereignty, broadly defined as the right of nations and peoples to control their own food systems... has emerged as a critical alternative to the dominant neoliberal model for agriculture and trade" (Wittman et al., 2010 , p. 2). Since the economic interests of multinational business and political forces in national government are aligned to drive most of the food research agenda, the global system is unlikely to meet the economic needs of most small farmers and rural people, and the food needs of other marginalized citizens. It is time to dedicate more research attention to local food systems and explore their potential to increase production diversity and resilience, improve nutrition and health outcomes, decrease hunger, restore rural economic viability, and improve the environment. We also need to investigate the importance of food sovereignty in a complex, unpredictable, and increasingly risky future.

\section{Sustainable Small- and Midscale Food Production}

The need to increase food production and availability by at least 70 percent by 2050 has been widely reported (Godfray et al., 2010), while some food requirements could be met by solving crop loss in the field and waste in the system that 
currently result in at least 30 percent loss before food reaches the table (Parfitt, Barthel, \& Macnaughton, 2010). There is limited research on the current contributions and potentials of smallscale and local food production since the majority of investment over the past eight decades has focused on refining the large-scale, chemicalintensive, industrial model that has dominated in the North. Among many priority research questions about small- and midscale farms are these:

- Efficiencies of resource use and production in diversified systems;

- Potentials of crop and animal integration for efficient resource use and resilience;

- Enterprise stacking with multiple animal species;

- Designs for multiple cropping systems and their mechanization;

- Biological intensification to increase production and resource use efficiency;

- Nutrient cycling on farms and from rural communities, including human waste;

- Permaculture systems with perennial and annual species plus animals;

- Aquaculture integrated with on-farm feed sources and water cycling;

- Perennial polycultures for integrated grain and forage production;

- Spatially vertical production systems and small-scale urban farming; and

- Urban production systems based on wastewater recycling.

In addition to the above research questions appropriate to small- and midscale farms, we also need to know how community gardens, urban farms, and personal home gardens can contribute to addressing immediate issues of hunger and access to fresh and healthy produce. While the resurgence in interest is far less than that which resulted in the 20 million "victory gardens" that helped supply 40 percent of the U.S. population with their fruits and vegetables during World War II, such gardens may alleviate hunger and negative health outcomes and should be evaluated as part of a vibrant local food system.

\section{Economic Opportunities for Local Food Systems}

Although economies of scale are generally attributed to large, mechanized farms, in fact there are many options to achieve similar results at a smaller scale. Hall and LeVeen (1978) reported that most efficiencies can be reached on modest-sized farms, and that many other measures beyond labor-saving technologies should be studied to understand small-farm economics. From analyses of farm size and resource use in Iowa corn-andsoybean farms, Tegtmeier and Duffy (2004) reported that most efficiencies of scale were achieved by farms of 640 acres (259 hectares). There is substantial data today on the total costs of growing food far from where it is consumed, yet applied research is needed to better understand the multiple benefits of sustainably produced local foods and improve understanding of the local multiplier effect in rural communities (Halweil, 2002). Among the important research areas are these:

- Impacts of farm size on production efficiency using metrics of labor and other inputs;

- Labor vs. technology trade-offs on smalland midscale farms;

- Measures of food-safety and food-quality components affected by distance to market;

- Optimum equipment size and economies of mechanization scale for small, local farms;

- Economics of on-farm and local processing of farm products for local sale;

- Multiplier effects of food dollars spent for locally grown and/or processed farm products;

- Added value to farm enterprises from direct or other models of local marketing;

- Economic resilience as a consequence of multiple enterprises and integration either on the farm or in a contiguous region; and

- Connecting regional food networks to meet temporary or ongoing needs in other regions. 


\section{Environmental Impacts of Small- and Midscale Farms}

Loss of biodiversity in rural landscapes has been attributed to increases in farm size, specialization in one or a few enterprises, large-scale mechanization including equipment size and irrigation systems, and removal of livestock from most farms. A case study of three townships in Iowa with data from 1937 to 2002 substantiates these claims (Brown \& Schulte, 2011), with observations of larger fields, more row crops, fewer forages and small grains, and loss of rural infrastructure. There is ongoing debate about environmental impacts related to farm size and application of technologies (Morris \& Burgess, 2012), but general agreement that smaller farms are managed with greater attention to each acre, appreciation of biodiversity and preservation of nonfarmed areas, and concern for maintaining a diversity of farm enterprises and integration of crops and livestock (Ahnström, Höckert, Bergeå, Francis, Skelton, \& Hallgren, 2009). Research areas that need attention include:

- Participation of small-, mid-, and large-scale farms in conservation programs;

- Farming practices related to environmental conservation on different farm sizes;

- Enterprise diversity and animal integration related to environmental impacts of farms;

- Impacts of free-range livestock enterprises on the environment;

- Intensive rotational grazing of livestock and its environmental impacts;

- Preservation of ecosystem services on small-, mid-, and large-scale farms; and

- Attitudes of farm owners about long-term conservation of natural resources.

\section{Community and Rural Infrastructure}

From the pioneering research in the Central Valley of California in the 1940s (Goldschmidt, 1948) to the present, there is convincing evidence that farm size is associated with local community economies, services, and quality of life. In fact, the results of the original studies were so controversial and negative toward large-scale agriculture that the California Farm Bureau attempted to squelch the initial research results and prevent Goldschmidt from receiving his degree from UCD. Recent research confirms many of Goldschmidt's results, and the impacts of corporate, industrial-model farming are even more accentuated with contemporary trends toward consolidation of land in fewer holdings (Lobao \& Stofferahn, 2008). Although we may operate in a more transparent research environment today, there is still an overwhelming level of research support from private industry and public-sector grants to support improvements in the dominant model of industrial agriculture, and researchers interested in small farms and local food systems often depend on small grants from the federal government, private foundations, or nonprofit organizations. Some research priorities for the future include:

- Impact of land, labor, and production resource distribution in rural communities;

- Quality of rural infrastructure and communities related to farm size and farm numbers;

- Food availability and quality related to strength of local small-farm production;

- Equity of access to food as related to local production and distribution webs;

- Impacts of local small- and midscale farms on food security, sovereignty, and/or cultural identity;

- Potentials for continuity over generations on smaller-scale sustainable farms;

- Effects of public policies to optimize contributions from local, small-, and midscale farms; and

- Economic and policy incentives to develop regional food networks.

Finally, research must address the price-toaccess conundrum. All consumers need access to healthy and fresh products, and thus we must avoid the disparity of two food systems: one for the wealthy with access to expensive fresh food, and one for the poor with access only to fast food and highly processed, calorie-dense options. Keeping food "cheap" is a societal issue, and the cost cannot be borne by farmers alone. If we continue to expect food prices to stay low at farmers' expense, then the erosion of the farming 
population (average age is now 59) will continue, without young people available to replace those transitioning out. Can we research and evaluate alternative models in which access and affordability of farmland are increased to those who can bring creative ideas to farming and food systems?

\section{Conclusions: A Call for Research and Education}

The potential for change in farming and food systems research priorities to consider local "foodsheds" (Getz, 1991) and provide objective analysis of local foods versus those from a "global everywhere" (Kloppenburg, Hendrickson, \& Stevenson, 1996) will depend on the results of the above research agenda plus the investigation of many related topics. We must keep in mind that the research results from studies of controversial topics may get little attention from farmers and other decision-makers, depending on their investment in the current industrial farming paradigm (Francis, 2010). It is difficult to objectively assess the long-term impacts of a move toward strengthening local, diversified, value-adding, and smalland midscale food systems since relatively little research has been done compared to that on largescale systems. Improvements will be driven in part by public awareness of the challenges in our current food system, and largely by educating the next generation of scientists in holistic, systemsoriented, transdisciplinary studies such as those presented in agroecology (Lieblein, Breland, Francis, \& Østergaard, 2012; Lieblein \& Francis, 2007) and systems dynamics (Maani \& Maharaj, 2004). Extension also plays a role in educating the public about local food systems (Dunning, Creamer, Massey Lelekaks, O’Sullivan, Thraves, \& Wymore, 2012).

Given the magnitude of global food challenges, projected increases in human population, losses of biodiversity and ecosystem services from rural landscapes, and growing interest in local foods through farmers' markets, CSAs, and direct purchase from farmers, it clearly is time to thoughtfully examine other alternatives. Questions of how to achieve food equity, food security, and local food sovereignty should be addressed as part of the future projections for a comprehensive agenda for research. To rely entirely on a global, specialized, and narrowly owned and tightly controlled industrial food system would appear to be ill-advised in light of the many emerging constraints on its sustainability. The human potential for creativity and contributions to future sustainable food systems can only be realized by exploring new paradigms that are outside the mainstream, and this we owe to coming generations. It is important to heed the words of Nobel laureate René Dubos that "Trend is not destiny."

\section{References}

Ahnström, J., Höckert, J., Bergeå, H. L., Francis, C. A., Skelton, P., \& Hallgren, L. (2009). Farmers and nature conservation: What is known about attitudes, context factors and actions affecting conservation? Renewable Agriculture and Food Systems, 24(1), 38-47. http://dx.doi.org/10.1017/S1742170508002391

Brown, P. W., \& Schulte, L. A. (2011). Agricultural landscape change (1937-2002) in three townships in Iowa, USA. Landscape Urban Planning, 100(3), 202-212. http://dx.doi.org/10.1016/j.landurbplan. 2010.12.007

Creamer, N. G., \& Dunning, R. D. (2012).Local food systems for a healthy population (Invited Commentary). North Carolina Medical Journal, 73(4), 310-314. PMID:23033726

Dunning, R., Creamer, N., Massey Lelekaks, J., O’Sullivan, J., Thraves, T. \& Wymore, T. (2012). Educator and institutional entrepreneur: Cooperative Extension and the building of localized food systems. Journal of Agriculture, Food Systems, and Community Development, 3(1), 99-112. http://dx.doi.org/10.5304/jafscd.2012.031.010

Francis, C. A. (2010). Conventional research on controversial issues: An exercise in futility? Renewable Agriculture and Food Systems Journal, 25(1), 3-7. http://dx.doi.org/10.1017/S1742170509990251

Getz, A. (1991).Urban foodsheds. Permaculture Activist, 24(10), 26-27.

Godfray, H. C. J., Beddington, J. R., Crute, I. R., Haddad, L., Lawrence, D., Muir, J. F.,...Toulmin, C. (2010). Food security: The challenge of feeding 9 billion people. Science, 327(5967), 812-818. http://dx.doi.org/10.1126/science. 1185383 
Goldschmidt, W. (1948). Down on the farm: New style. Antioch Review, 8(2), 179-192. http://dx.doi.org/10.2307/4609266

Hall, B. F., \& LeVeen, E. P. (1978). Farm size and economic efficiency: The case of California. American Journal of Agricultural Economics, 60(4), 589600. http://dx.doi.org/10.2307/1240243

Halweil, B. (2002). Home grown: The case for local food in a global market (Worldwatch paper no. 163). State of the World Library. Washington, D.C.: Worldwatch Institute. Retrieved from http://www.worldwatch.org

Kloppenburg Jr., J., Hendrickson, J., \&Stevenson, G. W.(1996). Coming into the foodshed. Agriculture and Human Values, 13(3), 33-42. http://dx.doi.org/10.1007/BF01538225

Kremen, C., Iles, A., \& Bacon, C. (2012). Diversified farming systems: An agroecological, systems-based alternative to modern industrial agriculture. Ecology and Society, 17(4), 44. http://dx.doi.org/10.5751/ES-05103-170444

Lieblein, G., Breland, T. A., Francis, C., \& Østergaard, E. (2012). Agroecology education: Action-oriented learning and research. Journal of Agricultural Education and Extension, 18(1), 27-40. http://dx.doi.org/10.1080/1389224X.2012.638781

Lieblein, G., \& Francis, C. (2007). Towards responsible action through agroecological education. Italian Journal of Agronomy, 2(2), 83-90. http://dx.doi.org/10.4081/ija.2007.83

Lobao, L., \& Stofferahn, C. W. (2008). The community effects of industrialized farming: Social science research and challenges to corporate farming laws. Agriculture and Human V alues, 25(2), 219-240. http://dx.doi.org/10.1007/s10460-007-9107-8

Maani, K. E., \& Maharaj, V. (2004). Links between systems thinking and complex decision making. System Dynamics Review, 20(1), 21-48. http://dx.doi.org/10.1002/sdr.281

Morris, J., \& Burgess, P. J. (2012). Modern agriculture and implications for land use and management. In
R. E. Hester \& R. M. Harrison (Eds.), Issues in Environmental Science and Technology: Vol. 34. Environmental impacts of modern agriculture (pp. 1-34). Cambridge, UK: Royal Society of Chemistry. http://dx.doi.org/10.1039/9781849734974-00001

Parfitt, J., Barthel, M., \& Macnaughton, S. (2010). Food waste within food supply chains: Quantification and potential for change to 2050. Philosophical Transactions of the Royal Society B, 365(1554), 30653081. http://dx.doi.org/10.1098/rstb.2010.0126

Postel, S. (2013). Sustaining freshwater and its dependents. In Worldwatch Institute and E. Assadourian (Eds.), State of the world 2013: Is sustainability still possible? (pp. 51-62). New York: WorldWatch Institute.

Renner, M. (2013). Climate change and displacements. In Worldwatch Institute and E. Assadourian (Eds.), State of the world 2013: Is sustainability still possible? (pp. 343-352). New York: WorldWatch Institute.

Tegtmeier, E. M., \& Duffy, M. D. (2004). External costs of agricultural production in the United States. International Journal of Agricultural Sustainability, 2(1), $1-20$.

http://dx.doi.org/10.1080/14735903.2004.9684563

Office of the Chief Scientist, U.S. Department of Agriculture [USDA]. (2012). Sustainable agricultural systems science white paper. Washington, D.C.: USDA. Retrieved from http://www.usda.gov/documents/sustainableagriculture-science-white-paper.pdf

Wittman, H., Desmarais, A. A., \& Wiebe, N. (Eds.). (2010). Food sovereignty: Reconnecting food, nature \& community. Nairobi: Pambazuka Press, Independent Publishing Group.

World Commission on Environment and Development [WCED]. (1987). Our common future. Oxford, UK: Oxford University Press.

Zencey, E. (2013). Energy as master resource. In Worldwatch Institute and E. Assadourian (Eds.), State of the world 2013: Is sustainability still possible? (pp. 73-83). New York: WorldWatch Institute. 